\title{
Konseling Daring Pendukung Siswa Cerdas (KDPSC): A Preliminary Evaluation of iCBT Treatments for Indonesian Freshmen with Social Anxiety
}

\author{
Kurnia Yohana Yulianti ${ }^{1}$, Yulia Wijayantiㄹ, Neila Ramdhani ${ }^{3}$ \\ 1,2,3Faculty of Psychology, Universitas Gadjah Mada \\ Submitted 16 March 2020 Accepted 18 May $2020 \quad$ Published 22 May 2020
}

\begin{abstract}
During the transition period from adolescence to adulthood, individuals with high level of social anxiety may face challenges in their academics, social life, and career. The internet-based Cognitive Behavior Therapy (iCBT) module "Konseling Daring Pendukung Siswa Cerdas" (KDPSC) was developed to intervene with the social anxiety experienced by Indonesian young adults. Fifteen university freshmen with moderate to high levels of social anxiety agreed to fully participate in all sessions of the program. The sessions were conducted under the guidance of registered psychologists through the chatting platform on Google Hangouts. Indonesian version of Social Anxiety Scale for Adolescents (SAS-A) were administered during the pretest and posttest. We initially conducted a qualitative assessment during the intervention and found three emergent themes at the beginning of Session Two, namely, loneliness, the feeling of having no choice, and social withdrawal. After the end of Session Two, three emergent themes were found; 1), positive thinking, 2) feeling academically motivated, and 3) intention to open up. The main finding showed that students' level of social anxiety after intervention $(M=58.07 ; S E=3.28 ; t(14)=4.250 ; p<0.01$; Cohen's $d=0.875)$ was significantly lower than before intervention $(M=67.20 ; S E=2.048)$. Further implications of the study are discussed.
\end{abstract}

Keywords: adolescents; iCBT; online counselling; social anxiety; students

Transition periods in the stages of human development provide opportunities for individuals to encounter new environments. Individuals who are unprepared and unable to adjust are vulnerable to psychological problems. One possible psychological problem experienced by such individual is social anxiety (Tillfors, Persson, Willén \& Burk, 2012).

Social anxiety is often experienced by adolescents (Ries Merikangas \& Nakamura, 2011; Tillfors et al., 2011). In Indonesia, quite a lot of people suffer from social an-

${ }^{1}$ Address of correspondence:

kurniayohana88@ugm.ac.id xiety. A preliminary study of this research found that $8 \%$ out of 222 respondents who were first year university students experienced a high level of social anxiety and $65 \%$ experienced medium level social anxiety. A study by Daulay and Ramdhani (2018) involving 18-25-year-old individuals found that $15.8 \%$ out of 311 subjects experienced social anxiety.

Social anxiety can be defined as an irrational fear of interacting with others, including fear of receiving criticism or meeting new people (Leary \& Kowalski, 1995; Swasti \& Martani, 2013). Symptoms of social anxiety may include depression or 
high levels of uneasiness without any particular triggers. Individuals who suffer from social anxiety fear being negatively judged by others (Leary \& Kowalski, 1995) and experience discomfort in social situations, especially in unfamiliar environments (La Greca \& Lopez, 1998). Subsequently, individuals with social anxiety tend to decrease the intensity by which they interact with others and even shy away from social situations in their daily lives (Leary \& Kowalski, 1995). It is evident that there is an interaction between the cognitive and behavioral processes of individuals with social anxiety.

Social anxiety can interfere with the daily activities of individuals who experience it, especially in terms of establishing relationships (Tillfors et al., 2012). Ramdhani, Widjaja, and Rahmawati (2015) noted that adolescents might experience shy-social isolated problems due to social anxiety and cognitive distortion. Adolescents experiencing social anxiety may also experience a decline in academic performance (Ranta et al., 2012).

Social anxiety may continue to worsen if one does not seek psychological treatment. However, difficulty to reach mental health service facilities and limited availability of professionals are factors that can prevent individuals with psychological problems from getting help to overcome their struggles (Putri, Yahya \& Saputra, 2019).

These limitations can be minimized by utilizing the presence of educational practitioners as counsellors, given that adolescents spend most of their time at school. A teacher should not only assist students in academic-related issues but also guide their social development (Jennings \& Greenberg, 2009). Lecturers and teaching staff are also considered some of the closest people students can rely on in the face of problems (Putri et al., 2019). However, in Indonesia, the actualization of educational practitioners' role as adolescents' support system in the face of psychological problems is still questionable.

A study by Putri et al. (2019) found that lecturers encounter difficulties in trying to assist students who experience problems. Lecturers have limited time for face-to-face discussions and also struggle with the unavailability of a private and comfortable space to discuss psychological issues experienced by students on campus.

On the other hand, people with social anxiety can experience chronic worries when having to deal with others, including interacting with counsellors who help them overcome their anxiety disorder (Woods et al., 2017). There is a need for a strategy that connects those who suffer social anxiety with counsellors without them having to conduct face-to-face counselling.

Internet as a product of information and communication technology development brings hope in overcoming these limitations. The internet allows counsellors and clients to interact and hold counselling sessions without a face-to-face meeting. Although online counselling cannot replace face-to-face counselling, it is an available option which can serve as the initial step in overcoming social anxiety (Woods et al., 2017). In a study by McKenna, Green, and Gleason (2002), participants who had social anxiety reported that they experienced decreasing 
levels of social anxiety after interacting with other people online for two years.

In the Global Digital Report 2019, WeAreSocial (2019) reported that Indonesian people spend an average of 8 hours 36 minutes per day accessing the internet through various digital devices, with 3 hours 26 minutes of the total said time accessed via smartphones. Approximately $33 \%$ of Indonesians who actively engage in social media via smartphones in Indonesia are those aged between 13 to 24 years old. The presence of the internet becomes not only the main modality to teach future generations, but also an opportunity for education practitioners (psychologists, teachers, policymakers) to conduct counselling and intervention online instead of face-to-face to increase effectiveness in promoting youth's mental health.

Students' busy schedules at school are often used as an excuse to not spare time for counselling. This reality indicates the need for online counselling services to overcome the limitations. Norcross, Hedges, dan Prochaska (2002) suggests that online counselling can be an alternative for distance barriers and limited communication time.

Given the interaction between cognitive and behavioral processes in individuals with social anxiety, the "Konseling Daring Pendukung Siswa Cerdas" program (KDPSC) is developed by adapting the principles of CBT. CBT aims to help individuals identify the source of psychological problems and acquire skills to overcome the problems (Wright, 2006). The objective of this program is achieved by emphasizing the process of cognitive identification and reconstruction, allowing individuals to identify maladaptive thoughts within themselves and subsequently seek alternative thoughts (Wright, 2006). In addition, individuals are also engaged in activities that improve coping skills, social skills, and problemsolving skills (Wright, 2006) through assignments and feedbacks provided by counsellors. In guided internet-based CBT, counsellors' feedbacks are considered a form of counsellor support (Andersson, Carlbring, Ljótsson \& Hedman, 2013).

Research on the use of internet-based brief CBT (iCBT) to cope with social anxiety was conducted by Daulay and Ramdhani (2018). Daulay and Ramdhani focus on subjects amidst a developmental transition from adolescence to adulthood; The subjects were aged between 18-25 years old, and the inclusion criteria did not specifically require participants to be university freshman students. The social anxiety scale used by Daulay and Ramdhani is an adaptation of the Interaction Anxiousness Scale (Leary, 1983), which focuses on the subjective component of anxiety during contingent social interaction, such as in one's interaction with his or her teacher or boss, opposite sex or during job interviews. The Interaction Anxiousness Scale (Leary, 1983) is widely used to measure social anxiety in adult individuals (Ingles, La Greca, Marzo, Garcia-Lopez \& Garcia-Fernandez, 2010).

In contrast to the research mentioned above, this study conducted a preliminary assessment regarding the effectiveness of the internet-based CBT brief (iCBT) in the form of the KDPSC program to overcome social anxiety in first-year university students experiencing a period of academic 


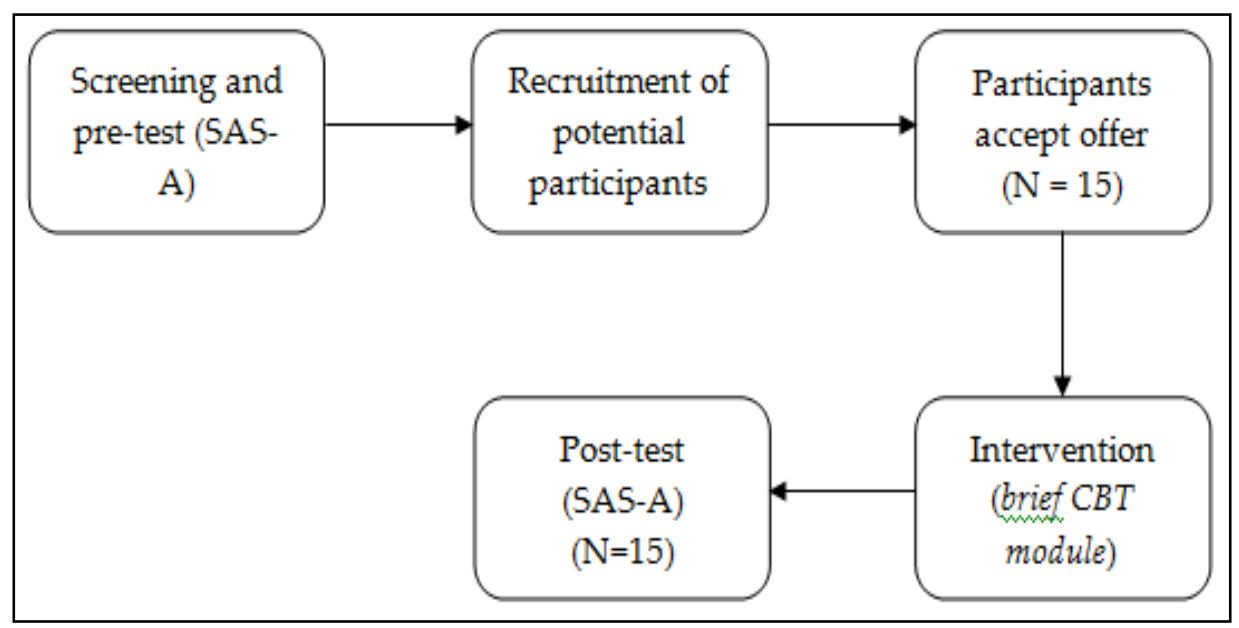

Figure 1. Flow chart of participant selection and research implementation

transition from high school to university.

The conceptual model of social anxiety referred to in this study primarily focused on adolescents. The three social anxiety factors in adolescents (Ingles et al., 2010) are (1) fear of negative evaluation which is related to fear and worry of being negatively evaluated by peers; (2) social avoidance and distress in a new situation which reflects the struggle of being in social situations that involves new or unfamiliar people; (3) social avoidance and distress in a general situation which relates to social obstacles, difficulties and discomfort in familiar situations.

The study hypothesized that the iCBT intervention reduces the level of students' social anxiety. During the intervention, researcher also collected qualitative data through open-ended questions as supporting data. The implications of this study can be used as a recommendation for the development of further online intervention programs focusing on improving self-help, peer support, client support, parental support, teacher support, and help-seeking attitudes.

\section{Method}

\section{Participants}

Selection of participants began by screening 222 first-year students at a university in Yogyakarta in September 2018. The screening was completed by filling out an online form containing the SAS-A scale; the links to the form were distributed in class. The screening identified 145 people with moderate levels of social anxiety (total score $=43-66$ ), and 17 people with high levels of social anxiety (total score $=67-90$ ). Students in both categories were offered to attend the KDPSC program via an e-mail sent by the researcher. Of those who were offered a place, 15 people gave confirmation and were willing to complete the whole process of the intervention (Figure 1).

\section{Design}

This study used a pretest posttest single group design, as illustrated in figure 2 .

The pretest-posttest single group is an experimental design used to conduct a preliminary assessment of programs (CaseSmith, Holland, Lane \& White, 2012; Fisak, 2014; Issel, 2004; Thyer, 2002) especially 
$\mathrm{O}_{1}$

$\mathrm{O}_{1} \quad$ : $\quad$ Before treatment

X : $\quad$ Treatment

$\mathrm{O}_{2} \quad: \quad$ After treatment
$X$

$\mathrm{O}_{2}$

Figure 2. Pretest-posttest single group design

when the presence of comparison or control group is not possible (Marlow, 2011). Without overlooking its limitations, there were several ethical and technical considerations taken into account in order to determine the research design. One ethical consideration related to the 15 participants' willingness to take part in the program for five weeks, subsequently restricting the presence of a no-treatment group or waiting list participants who must be treated at a later stage. Participants can belong to the same community and be familiar with one another. Participants in the control group may have experienced discomfort due to being given a different Table 1

Brief CBT Module

\begin{tabular}{ll}
\hline Week & \multicolumn{1}{c}{ Session } \\
\hline 1 & 1: "Let us start a change." \\
2 & 2: "Things are not that bad." \\
3 & 3: "Everything is beginning to be \\
under control." \\
5 & 4: "The new me." \\
5 & 5: "Evaluation and termination."
\end{tabular}

treatment or receiving treatment at different time. This is also related to technical limitations, such as the limited number and availability of psychologists guiding the intervention as well as the research budget.

\section{Module}

The Brief CBT module used in the KDPSC program is an adaptation of a module developed by Daulay and Ramdhani (2018). In this program, the module content was modified to include material on social adaptation during the academic transition period. The online counselling process utilized the chat feature on the Google Hangout platform as a media to deliver modules from the counsellor to the client. The Google Hangout platform facilitated the sending of private messages enabling counsellors to build personal interactions with the clients. The series of intervention sessions are briefly described in Table 1.

\section{Annotation}

Psychoeducation regarding social anxiety during academic transitions and iCBT

Identifying maladaptive thoughts and seeking alternative thoughts

Writing down activities the participants want to do

Writing down a problem-solving plan

\section{Instruments}

This research employed the Social Anxiety Scale for Adolescents (SAS-A) by La Greca \& Lopez (1998), that consists of 18 items measuring the following aspects: Fear of Negative Evaluation (FNE), Social 
Table 2.

Aspects and Example Items of SAS-A

\begin{tabular}{|c|c|c|}
\hline Aspect & Item Example & $\begin{array}{c}\text { Item } \\
\text { Number }\end{array}$ \\
\hline \multirow[t]{3}{*}{$\begin{array}{l}\text { Fear of Negative } \\
\text { Evaluation (FNE) }\end{array}$} & $\begin{array}{l}\text { I feel like my peers are talking about me behind } \\
\text { my back }\end{array}$ & (6) \\
\hline & I worry about what other people think of me & (8) \\
\hline & I worry people do not like me & (9) \\
\hline \multirow{3}{*}{$\begin{array}{l}\text { Social Avoidance and } \\
\text { Distress in New } \\
\text { Situation (SAD-New) }\end{array}$} & $\begin{array}{l}\text { I worry about having to do something in front of } \\
\text { others }\end{array}$ & (1) \\
\hline & I feel shy around people I do not know & $(4)$ \\
\hline & I get nervous when having to meet new people & (13) \\
\hline \multirow{3}{*}{$\begin{array}{l}\text { Social Avoidance and } \\
\text { Distress in General } \\
\text { Situation (SAD-General) }\end{array}$} & $\begin{array}{l}\text { I tend to stay quiet when I am with a group of } \\
\text { people }\end{array}$ & (15) \\
\hline & $\begin{array}{l}\text { I feel afraid of inviting people to do things with } \\
\text { me because I am afraid that they might say no }\end{array}$ & $(19)$ \\
\hline & I feel shy even with peers I know well & $(21)$ \\
\hline
\end{tabular}

Avoidance and Distress in New Situation (SAD-New), and Social Avoidance and Distress in General Situation (SADGeneral). Each statement in this scale is rated on a score of 1 to 5 according to the participants' condition (never, seldom, sometimes, almost always, always). The researcher modified the SAS-A scale in Indonesian language and acquired a Cronbach's alpha of 0.903 with the index of item discrimination power ranging between $r=0.373-0.767$. Example of statements in the SAS-A can be seen in Table 2.

\section{Data analysis}

Hypothesis testing was conducted using a $t$ test to identify differences in levels of social anxiety before and after the intervention. Additionally, the analysis of qualitative results employed thematic analysis techniques (Braun \& Clarke, 2006) to acquire a detailed understanding of the themes that emerged from the participants' answers.

\section{Results}

Main findings

Based on Table 3, the participants' average score in the SAS-A experienced a decline from 67.2 to 59.7. The change in participants' SAS-A scores before and after the intervention can be seen in Figure 3.

Before hypothesis testing, the researcher conducted assumption testing to check for data normality (Field, 2009). The Shapiro Wilk test showed that the data from this study were normally distributed $(p>$ 0.05).

Researchers conducted statistical testing using a t-test. The analysis showed that there were significant differences in the level of social anxiety among the participants before $(M=67.20 ; S E=2.048)$ and after being treated $(M=58.07 ; S E=3.28$; $t(14)=4.250) ; p<0.01$ ) with a large effect size (Cohen's $d=0,875$ on the posttest). Statistical results indicate that the iCBT intervention program has the potential to reduce students' social anxiety in students. 
Table 3.

Result of Pretest dan Posttest SAS-A Score

\begin{tabular}{ccc}
\hline & & SAS-A score \\
\cline { 2 - 3 } Subject & Pretest & Posttest \\
\hline A & 57 & 35 \\
B & 58 & 42 \\
C & 72 & 63 \\
D & 69 & 73 \\
E & 69 & 58 \\
F & 59 & 48 \\
G & 65 & 66 \\
H & 56 & 53 \\
I & 67 & 63 \\
J & 70 & 69 \\
K & 63 & 48 \\
L & 77 & 76 \\
M & 85 & 72 \\
N & 72 & 60 \\
O & 69 & 45 \\
\hline Average & 67.2 & 59.7 \\
\hline
\end{tabular}

Specifically, a significant decrease in participants' social anxiety levels was seen in the aspects of "fear of negative evaluation" (Figure 4) and "social avoidance and distress in a new situation" (Figure 5).
In the aspect of FNE the average score of participants shifted from 31.47 to 27.02 ( $p<$ 0.05 ; Cohen's $d=0.748$ ). The average score of participants on the aspect of SAD-New shifted from 22.93 to 19.13 ( $p<0.05$; Cohen's

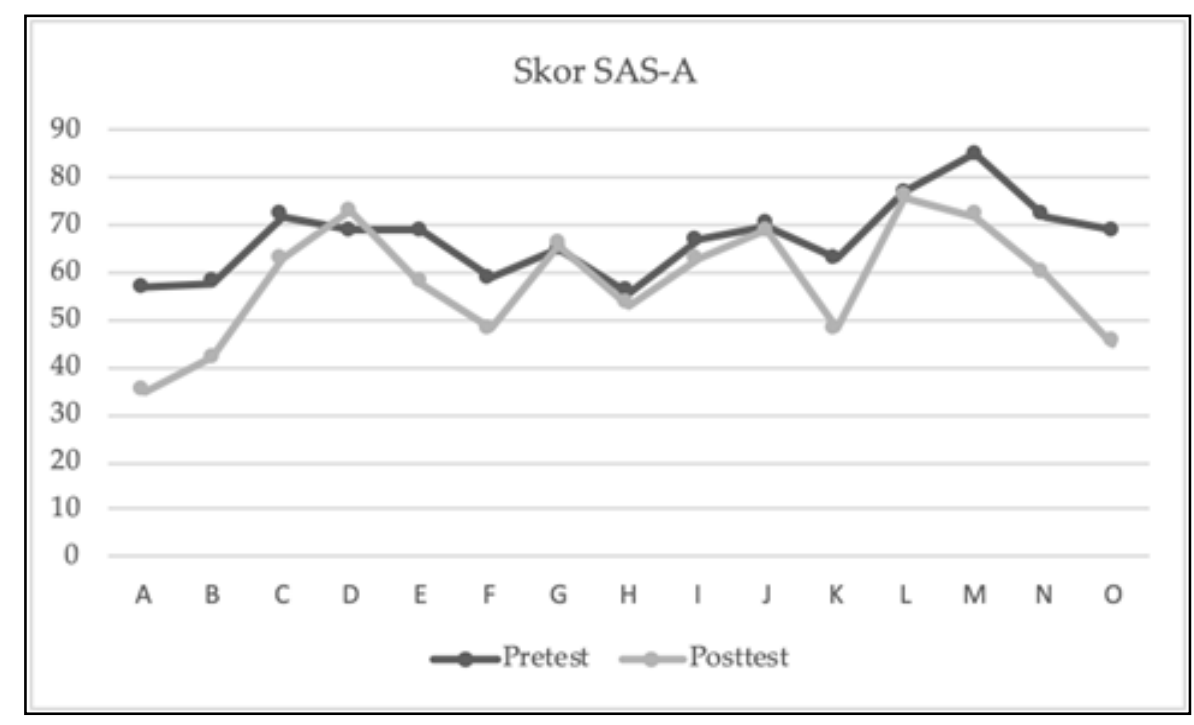

Figure 3. SAS-A total scores 


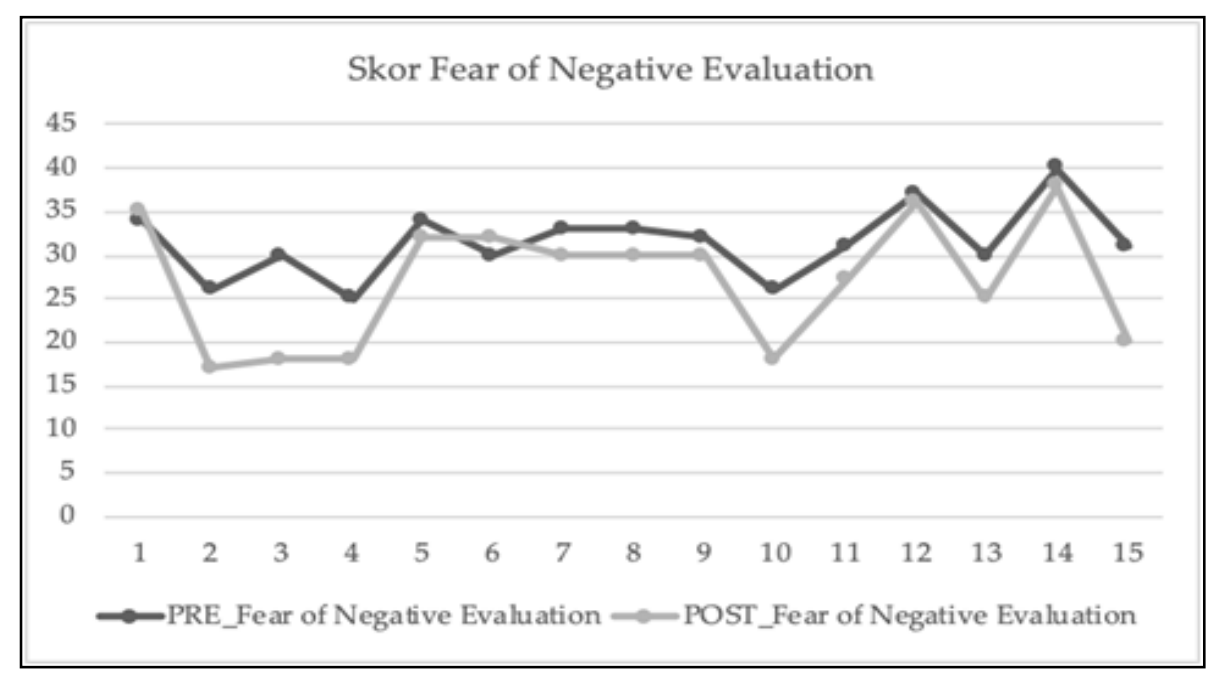

Figure 4. Scores on the FNE

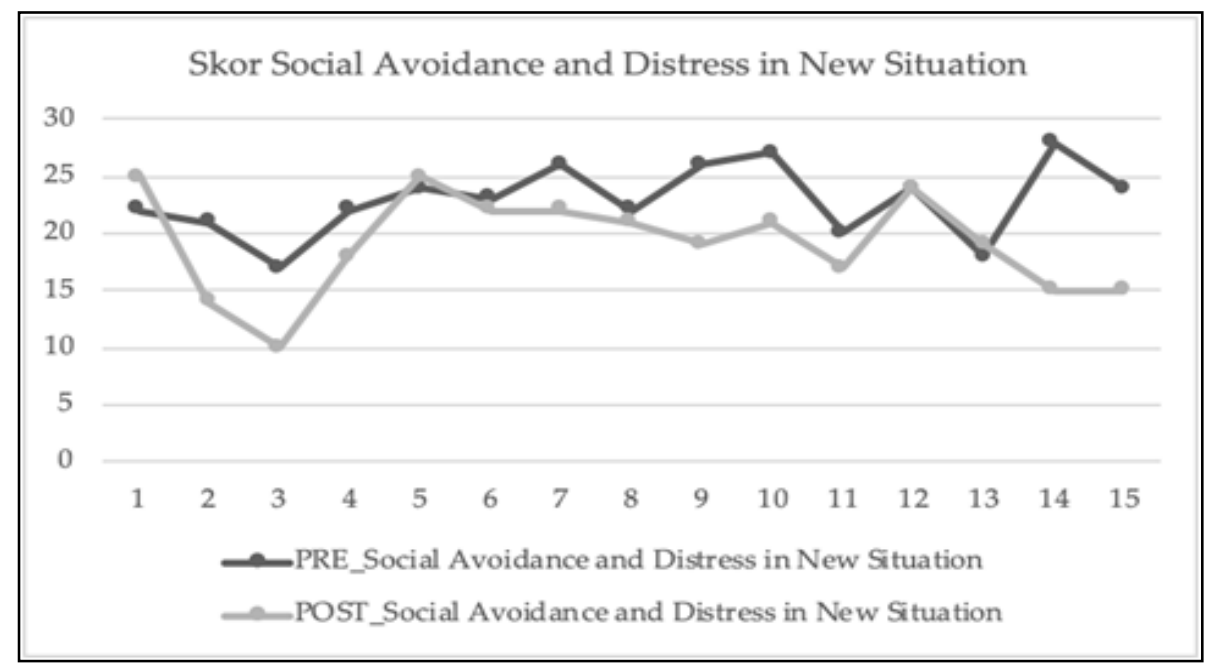

Figure 5. Scores on SAD-New

$d=0.999)$, while in the average score on SAD-General (Figure 6) the participants did not experience a significant decrease (mean 1 $=12.80$; mean $_{2}=11.87 ; p>0.05$ ).

\section{Additional findings during the intervention}

In Session 2, participants were invited to identify and overcome maladaptive thoughts. The purpose of this session was to assist participants in generating positive alternative thoughts. At the beginning of this session, participants were given a narrative illustration of social anxiety problems experienced by $\mathrm{X}$ and $\mathrm{Y}$. Then participants answered the open question "If you were in the position $X$ and $Y$, how would you feel?". Based on the participants' answers, we conducted a thematic analysis (Braun \& Clarke, 2006) and obtained several emergent themes including loneliness, the feeling of having no choice, and social withdrawal (Table 4).

At the end of Session 2, the counsellor engaged participants in seeking alternative thoughts to make $X$ and $Y$ can feel better. In addition, participants reflected on their thoughts and feelings through the question "If you were $X$ and $Y$, how would you feel 


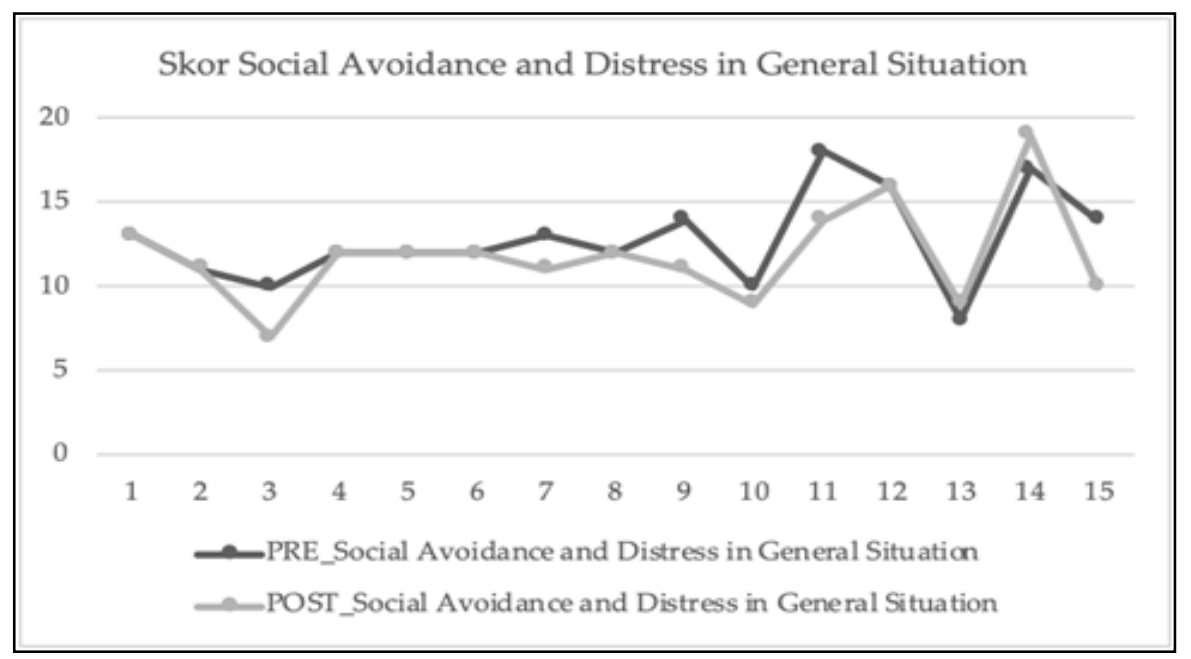

Table 4 .

Figure 6. Scores on SAD-General

Thematic Analysis of "If you were in the position of X and $Y$, how would you feel?"

\begin{tabular}{|c|c|c|}
\hline Theme & Definition & Sample of Subjects' Answers \\
\hline Loneliness & $\begin{array}{l}\text { Individuals } \\
\text { difficulty interacting } \\
\text { with others, feel } \\
\text { uncomfortable, feel } \\
\text { lonely, and have no } \\
\text { friends. }\end{array}$ & $\begin{array}{l}\text { "Feel lonely and struggle due to having no } \\
\text { friends" }(\mathrm{O}, \mathrm{X}) \\
\text { "... I have a lot of friends here but none of them } \\
\text { are as fun and comfortable as my high } \\
\text { school friendships. I am sad." (C, Y) } \\
\text { "Stressed and lonely" (A, X) }\end{array}$ \\
\hline $\begin{array}{l}\text { The feeling of } \\
\text { having no } \\
\text { choice }\end{array}$ & $\begin{array}{l}\text { Individuals regret } \\
\text { their choices and are } \\
\text { in despair, but do } \\
\text { not want to } \\
\text { disappoint their } \\
\text { parents. }\end{array}$ & $\begin{array}{l}\text { "I will feel the same way as Santi. Feel hopeless } \\
\text { and regret my decisions" (I, Y) } \\
\text { "I feel hopeless too, but I don't want to give up. } \\
\text { Because I think about my parents." (L, Y) } \\
\text { "I ... am afraid I am going to fail academically. } \\
\text {... I am even more afraid of disappointing } \\
\text { my parents in my hometown...." (C, Y) }\end{array}$ \\
\hline $\begin{array}{l}\text { Social } \\
\text { Withdrawal }\end{array}$ & $\begin{array}{l}\text { Individuals worry } \\
\text { about being } \\
\text { negatively judged by } \\
\text { friends, } \\
\text { subsequently close } \\
\text { off themselves and } \\
\text { withdraw from the } \\
\text { environment. }\end{array}$ & $\begin{array}{l}\text { "Tired, (too) lazy to go to campus, want to } \\
\text { hurry home, more comfortable spending } \\
\text { time alone,..." (A, Y) } \\
\text { "Afraid and paranoid that friends may think I } \\
\text { am not fun...." (D, X) } \\
\text { "...I want to mingle and try to become } \\
\text { chummier with my friends, but negative } \\
\text { thoughts continue to bother me. And } \\
\text { eventually I would choose to be quiet and } \\
\text { withdraw from them." (I, X) }\end{array}$ \\
\hline
\end{tabular}

after discovering that alternative thought?".

The thematic analysis found several emergent themes, namely positive thinking, feeling academically motivated, and having the intention to open up (Table 5).
It should be underlined that this data only illustrates the assessment process of Session 2 and does not constitute the overall program evaluation. 
Table 5.

Thematic Analysis of Post-test

\begin{tabular}{|c|c|c|}
\hline Theme & Definition & Sample of Subjects' Answers \\
\hline $\begin{array}{l}\text { Positive } \\
\text { thinkin } \\
\mathrm{g}\end{array}$ & $\begin{array}{l}\text { Individuals feel grateful } \\
\text { for what has } \\
\text { happened, feel calm, } \\
\text { and optimistic about } \\
\text { living their academic } \\
\text { life }\end{array}$ & $\begin{array}{l}\text { "I will feel more optimistic, think and act } \\
\text { more positive." }(\mathrm{K}, \mathrm{X}) \\
\text { "Indeed, I will feel more at peace ..." }(\mathrm{C}, \mathrm{X}) \\
\text { "I will be more grateful for what I have ..." } \\
\quad(\mathrm{K}, \mathrm{Y})\end{array}$ \\
\hline $\begin{array}{l}\text { Feeling } \\
\text { academicall } \\
\text { y motivated }\end{array}$ & $\begin{array}{l}\text { Individuals are keen to } \\
\text { take part or continue } \\
\text { with academic } \\
\text { activities }\end{array}$ & $\begin{array}{l}\text { "I will feel more motivated to study, so I do } \\
\text { not get left behind by my friends who } \\
\text { think they are 'better'...." (D, X) } \\
\text { "Have a new start, motivated to create a new } \\
\text { learning environment" (A, X) } \\
\text { "More enthusiastic in doing assignments" (B, } \\
\text { Y) }\end{array}$ \\
\hline $\begin{array}{c}\text { Intention to } \\
\text { open up }\end{array}$ & $\begin{array}{l}\text { Individuals have more } \\
\text { courage to interact } \\
\text { and communicate } \\
\text { with other people } \\
\text { and face social } \\
\text { situations around } \\
\text { them. }\end{array}$ & $\begin{array}{l}\text { "... will communicate with family (members) } \\
\text { more often" (N, Y) } \\
\text { "... I will feel enlightened and attempt to join } \\
\text { organizations outside of my comfort zone." } \\
\text { (D, Y) } \\
\text { "I will ... become a more flexible person in } \\
\text { facing any kind of situation." }(\mathrm{K}, \mathrm{Y})\end{array}$ \\
\hline
\end{tabular}

\section{Discussion}

Social anxiety is one of the most common psychological problems experienced by adolescents transitioning to adulthood (Daulay \& Ramdhani, 2018; Tillfors et al., 2011). Social anxiety is marked by fear of negative evaluation, social avoidance and distress in a new situation and social avoidance and distress in the general situation (La Greca \& Lopez, 1998). Pretest of this study indicated that the participants had high scores on aspects of fear of negative evaluation (FNE) and social avoidance and distress in general situation (SAD-General). Additionally, the average participants are at a medium level in terms of social avoidance and distress in new situation (SAD-New). During adolescence, social evaluation and acceptance from peers play a role in well-being and happiness (Karaşar \& Baytemir, 2018). A study by Alkhathami (2015) found that cognitive aspects, in this case, fear of negative evaluation, negatively correlates with the quality of life in adolescents. One of the causes of this persistent negative evaluation and belief is cognitive dysfunction (Cartwright-Hatton, Tschernitz \& Gomersall, 2005; Spence, Donovan \& Brechman-Toussaint, 2000). First-year university students who experience social anxiety are at risk of experiencing difficulties adapting to a relatively new academic environment and culture (Arjanggi \& Kusumaningsih, 2016). 
The KDPSC was designed by taking into consideration principles of cognitive behavioral therapy (CBT), aiming to help individuals reconstruct positive and minimize misleading thoughts that may cause social anxiety. Offline CBT conducted in groups has proven effective in the intervention of children and adolescents with social anxiety (Ciuca, Berger \& Miclea, 2017; Herbert et al., 2009; Schulz, Vincent \& Berger, 2017). However, considering the characteristics of individuals with social anxiety (Tillfors et al., 2011; Woods et al., 2017) as well as the minimum health services and professionals (Putri et al., 2019), internet-based CBT internet can become an alternative individual-level intervention for social anxiety which has been proven to work in an adolescent sample (Spence et al., 2008; Tillfors et al., 2011).

According to Beck and Dozois (2011), the intervention process in a CBT begins with the identification of maladaptive thoughts (exploration). Then testing was conducted to see whether thoughts were in line with reality as a consideration to deal with maladaptive beliefs, seek alternative thoughts (examination), and validate one's belief system (experimentation). This approach targets an individual's automatic thoughts, transforming maladaptive thoughts into adaptive thoughts

Automatic thoughts are the surfacelevel flow of thoughts used in specific situations in everyday life to assess oneself and the environment. The functions of automatic thoughts are related to the deeper layers of human cognitive systems, namely cognitive schemes or core beliefs (Beck \& Dozois, 2011; Wright, 2006). Cognitive schemes allow more efficient information processing (automatic thought), thereby affecting individual behavior (Beck \& Dozois, 2011; Calvete, Orue \& Hankin, 2013). If an individual has a maladaptive scheme or belief, the individual will have maladaptive automatic thoughts that will affect their individual behavioral response.

At the beginning of Session 2, results of qualitative assessment indicated that the subjects experienced a fear of negative evaluation. In this case, the theme social withdrawal refers to a subject's tendency to avoid social activities/interactions or not voice their opinion for fear of being negatively judged by peers. This behavior is influenced by the subjects' maladaptive scheme via automatic thoughts (Calvete et al., 2013). Therefore, before addressing the behavioral aspects, the maladaptive aspects of the subjects' cognition need to be altered. This alteration was conducted in Session 2.

In session 2, the counsellor conducted a Socratic dialogue with each subject, which is a guided discovery method done by asking a series of questions to help the subject define the problem, identify thoughts and beliefs, see the meaning of events, and assess the consequences of thought or behavior. The process allows subjects to see different perspectives in assessing themselves and the situation at hand (Beck \& Dozois, 2011; Wright, 2006). Counsellors used case illustrations as media to conduct Socratic dialogue. Thus, participants identified negative thoughts and overcome cognitive distortion by studying case illustrations.

From the process of conducting Session 2 and studying positive alternative thoughts, the thematic analysis uncovered 
three themes that exhibited a change in the subjects' responses to a more positive direction. These three emergent themes are positive thinking, feeling academically motivated, and having intention to open up. Changes in the subject responses in this session indicate the outcomes of the KDPSC program in reconstructing the subjects' thoughts. Subjects are guided to recognize their cognitive distortions, then overcome the distortions through Socratic dialogue which encourages the emergence of alternative thoughts or more adaptive thoughts. Glanz, Rimer, and Viswanath (2008) argued that cognitive aspects determine the motivation or intention of individual behavior, and changes in cognitive aspects effectively influence individual behavior. Consequently, the subjects were expected to experience an increase in motivation to change their behavior after having adaptive beliefs and thoughts.

Quantitative data analysis conducted using t-test shows a significant difference between the level of participants' social anxiety during pretest and posttest. This significant difference is accompanied by large effect size. Specifically, the data shows a significant decrease in the FNE aspect (with medium effect size) and the SADNew aspect (with high effect sizes) two weeks after the intervention was carried out. Fear of negative evaluation, as well as social avoidance and distress in new situations, is a typical experience when entering new situations and social environments (Vernberg et al., 1992). This is due to the importance of peer social support which encourages individuals to build new relationships (Ranta, La Greca, Garcia-
Lopez \& Marttunen, 2015). The need for social support also leads to the need for a high social acceptance. This situation leads individuals to develop a fear of being negatively judged by others and try to build a positive impression (Karaşar \& Baytemir, 2018) causing social anxiety (La Greca \& Lopez, 1998). The preliminary evaluation of the KDPSC program shows that online counselling can be an efficient alternative in reducing the level of social anxiety in firstyear university students, specifically in relation to aspects of fear of negative evaluation, social avoidance, and distress in a new situation. Meanwhile, it can support their academic adjustment (Arjanggi \& Kusumaningsih, 2016). According to Vernberg et al. (1992), the manifestation of the social avoidance and distress in general situation may not yet be obvious during the transition period even though it might have already occurred. This may be the reason why social avoidance and distress in general situations aspects (SAD-General) were not seen following the execution of the KDPSC program.

The implementation of the KDPSC program was supported by professionals who provided guidance during the online counselling process. A meta-analysis study by Richards and Richardson (2012) reported that therapist-guided iCBT showed better outcome and retention in clients with psychological problems. In iCBT, professionals play the role of agents who help clients build a positive self-efficacy through assignment feedback. Notwithstanding, a study by Furmark et al. (2009) found that clients who attend unguided iCBT based on literature exhibited larger growth compared to those 
who completed a guided iCBT. Several recent studies (Dear et al., 2015; Morgan et al., 2017) note that unguided iCBT is also beneficial in handling depression and anxiety because it is feasible for clients who would like to remain anonymous or desire unguided self-treatment. Additionally, unguided iCBT is deemed more costeffective and can be an alternative to the limited number of professionals (Dear et al., 2015). Further study is needed to see the effectiveness of both guided and unguided iCBT, especially in treating social anxiety in Indonesian university freshmen.

This research used pretest posttest single group design with a small-sized sample. Although this design allows researchers to see changes in the mean scores of participants before and after being treatment (Engel \& Schutt, 2017; Marlow, 2011), program effectiveness still needs to be assessed with a robust research design. Additionally, the preliminary evaluation (posttest) of the KDPSC program was conducted two weeks after the series of interventions were completed. This minimizes the effects of maturation and spontaneous remission whereby the participants' social anxiety decreases between the time of post-intervention and posttest due to a learning process (e.g., getting used to the academic environment and new friendships) that has nothing to do with the intervention. Future research can consider a randomized controlled trial (RCT) with a larger sample to improve the generalizability of findings and minimize bias and confounding variables. Furthermore, a follow-up study needs to be carried out, primarily to examine social and distress in general situations experienced by individuals in familiar situations. In the context of adolescent social relations, avoidance, and social barriers in familiar situations can lead to clinical problems, such as social phobia (La Greca \& Lopez, 1998).

\section{Conclusion}

Although online counselling cannot replace the essence of face-to-face counselling, preliminary studies on the effectiveness of the KDPSC program show that online therapy can serve as an alternative preliminary intervention for first-year university students experiencing social anxiety, primarily to address aspects of fear of negative evaluation as well as social avoidance and distress in new situations.

\section{Recommendation}

The KDPSC program can be integrated with universities' mental health services. The identification and intervention of psychological problems experienced by first-year students need to be done as early as possible in an effort to prevent clinical problems such as self-harm and suicide. In addition, internet-based CBT programs can help students improve literacy about mental health, understand their experience of psychological problems, and encourage help-seeking behavior (Griffiths et al., 2017).

\section{References}

Alkhathami, S. (2015). Social anxiety and quality of life in adolescents: Cognitive aspect, social interaction and cultural tendency (Unpublished doctoral dissertation). Luton: University of 
Bedfordshire.

Andersson, G., Carlbring, P., Ljótsson, B., \& Hedman, E. (2013). Guided internetbased CBT for common mental disorders. Journal of Contemporary Psychotherapy, 43(4), 223-233. doi: 10.1007/s10879-013-9237-9

Arjanggi, R., \& Kusumaningsih, L. P. S. (2016). The correlation between social anxiety and academic adjustment among freshmen. Procedia - Social and Behavioral Sciences, 219, 104-107. doi: http10.1016/j.sbspro.2016.04.049

Beck, A. T., \& Dozois, D. J. A. (2011). Cognitive therapy: Current status and future directions. Annual Review of Medicine, 62(1), 397-409. doi: 10.1146/annurev-med-052209-100032

Braun, V., \& Clarke, V. (2006). Using thematic analysis in psychology. Qualitative Research in Psychology, 3(2), 77-101.

Calvete, E., Orue, I., \& Hankin, B. L. (2013). Early maladaptive schemas and social anxiety in adolescents: The mediating role of anxious automatic thoughts. Journal of Anxiety Disorders, 27(3), 278288. doi: $10.1016 / j . j a n x d i s .2013 .02 .011$

Cartwright-Hatton, S., Tschernitz, N., \& Gomersall, H. (2005). Social anxiety in children: Social skills deficit, or cognitive distortion? Behaviour Research and Therapy, 43(1), 131141.doi: $10.1016 / j . b r a t .2003 .12 .003$

Case-Smith, J., Holland, T., Lane, A., \& White, S. (2012). Effect of a coteaching handwriting program for first graders: One-group pretest-posttest design. American Journal of Occupational Therapy, 66(4), 396-405. doi: $10.5014 /$ ajot.2012.004333

Ciuca, A. M., Berger, T., \& Miclea, M. (2017). Maria and Andrea: Comparing positive and negative outcome cases in an online, clinician-guided, selfhelp intervention for panic disorder. Pragmatic Case Studies in
Psychotherapy, 13(3), 173-216. doi: 10.14713/pcsp.v13i3.2011

Daulay, F., \& Ramdhani, N. (2018). Konseling Online berbasis brief CBT dapat menurunkan kecemasan sosial. (Unpublished master thesis). Yogyakarta: Universitas Gadjah Mada.

Dear, B. F., Zou, J. B., Ali, S., Lorian, C. N., Johnston, L., Terides, M. D., Staples, L. G., Gandy, M., Fogliati, V. J., Klein, B., \& Titov, N. (2015). Examining selfguided internet-delivered cognitive behavior therapy for older adults with symptoms of anxiety and depression: Two feasibility open trials. Internet Interventions, 2(1), 17-23. doi: 10.1016/j.invent.2014.11.002

Engel, R. J., \& Schutt, R. K. (2017). The practice of research in social work. Thousand Oaks: SAGE Publications, Inc.

Field, A. (2009). Discovering statistics using SPSS (3rd ed.). Thousand Oaks: SAGE Publications, Inc.

Fisak, B. (2014). The prevention of anxiety in preschool-aged children: Development of a new program and preliminary findings. Mental Health and Prevention, 2(1-2), 18-25. doi: 10.1016/j.mhp.2014.07.001

Furmark, T., Carlbring, P., Hedman, E., Sonnenstein, A., Clevberger, P., Bohman, B., Eriksson, A., Hållén, A., Frykman, M., Holmström, A., Sparthan, E., Tillfors, M., Ihrfelt, E. N., Spak, M., Eriksson, A., Ekselius, L., \& Andersson, G. (2009). Guided and unguided self-help for social anxiety disorder: Randomized controlled trial. British Journal of Psychiatry, 195(5), 440-447. doi: 10.1192/bjp.bp.108.060996

Glanz, K., Rimer, B. K., \& Viswanath, K. (2008). Health behavior and health education: Theory, research, and practice (4th ed.). Hoboken: John Wiley \& 
Sons, Inc.

Griffiths, K. M., Walker, J., \& Batterham, P. J. (2017). Help seeking for social anxiety: A pilot randomised controlled trial. Digital Health, 3, 1-12. doi: $10.1177 / 2055207617712047$

Herbert, J. D., Gaudiano, B. A., Rheingold, A. A., Moitra, E., Myers, V. H., Dalrymple, K. L., \& Brandsma, L. L. (2009). Cognitive behavior therapy for generalized social anxiety disorder in adolescents: A randomized controlled trial. Journal of Anxiety Disorder, 23(2), 167-177. doi: 10.1016/j.physbeh.2017.03.040

Ingles, C. J., La Greca, A. M., Marzo, J. C., Garcia-Lopez, L. J., \& GarciaFernandez, J. M. (2010). Social Anxiety Scale for Adolescents: Factorial invariance and latent mean differences across gender and age in Spanish adolescents. Journal of Anxiety Disorders, 24(8), 847-855. doi: 10.1016/j.janxdis.2010.06.007

Issel, L. M. (2004). Health program planning and evaluation: A practical, systematic approach for community health. Burlington: Jones and Barlett Publisher.

Jennings, P. A., \& Greenberg, M. T. (2009). The prosocial classroom: Teacher social and emotional competence in relation to student and classroom outcomes. Review of Educational Research, 79(1), 491-525. doi: 10.3102/0034654308325693

Karaşar, B., \& Baytemir, K. (2018). Need for social approval and happiness in college students: The mediation role of social anxiety. Universal Journal of Educational Research, 6(5), 919-927. doi: 10.13189/ujer.2018.060513

La Greca, A. M., \& Lopez, N. (1998). Social anxiety among adolescents: Linkages with peer relations and friendship. Journal of Abnormal Child Psychology, 26(2),

83-94.

doi: 10.1023/a:1022684520514

Leary, M. R. (1983). Social anxiousness: The construct and its measurement. Journal of Personality Assessment, 47(1), 66-75. doi: 10.1207/s15327752jpa4701_ 8

Leary, M. R., \& Kowalski, R. M. (1995). Social anxiety. New York: The Guildford Press.

Marlow, C. R. (2011). Research methods for generalist social work (5th ed.). Lorong Chuan: CENGAGE Learning.

McKenna, K. Y. A., Green, A. S., \& Gleason, M. E. J. (2002). Relationship formation on the internet: What's the big attraction? Journal of Social Issues, 58(1), 9-31. doi: 10.1111/1540$\underline{4560.00246}$

Morgan, C., Mason, E., Newby, J. M., Mahoney, A. E. J., Hobbs, M. J., McAloon, J., \& Andrews, G. (2017). The effectiveness of unguided internet cognitive behavioural therapy for mixed anxiety and depression. Internet Interventions, 10(October), 4753. doi: $10.1016 /$ j.invent.2017.10.003

Norcross, J. C., Hedges, M., \& Prochaska, J. O. (2002). The face of 2010: A Delphi poll on the future of psychotherapy. Professional Psychology: Research and Practice, 33(3), 316-322. doi: 10.1037//0735-7028.33.3.316

Putri, A. K., Yahya, A. N. F., \& Saputra, A. R. (2019). Indonesian faculty barriers in providing help to college students in distress. Journal of College Student Retention, $\quad 0(0)$, 1-16. doi: $\underline{10.1177 / 1521025119880821}$

Ramdhani, N., Widjaja, J. D., \& Rahmawati, N. (2015). Internet supported cognitive behavior therapy to help students with shy-socially isolated problems. Procedia - Social and Behavioral Sciences, 165, 179-188. doi: 10.1016/j.sbspro.2014.12.620

Ranta, K., La Greca, A. M., Garcia-Lopez, L.J., \& Marttunen, M. (2015). Social 
anxiety and phobia in adolescents: Development, manifestation, and intervention strategies. New York: Springer International Publishing.

Ranta, K., Junttila, N., Laakkonen, E., Uhmavaara, A., Greca, A. M. La, \& Niemi, P. M. (2012). Social Anxiety Scale for Adolescents (SAS-A): Measuring social anxiety among finnish adolescents. Child Psychiatry $\mathcal{E}$ Human Development, 43, 574-591. doi: 10.1007/s10578-012-0285-2

Richards, D., \& Richardson, T. (2012). Computer-based psychological treatments for depression: A systematic review and meta-analysis. Clinical Psychology Review, 32(4), 329342. doi: 10.1016/j.cpr.2012.02.004

Ries Merikangas, K., \& Nakamura, E. F. (2011). The epidemiology of depression and anxiety in children and adolescents. In M. T. Tsuang, M. Tohen, \& P. B. Jones (Eds.), Textbook in Psychiatric Epidemiology: Third Edition (3rd ed., pp. 435-448). Hoboken: John Wiley \& Sons, Ltd.

Schulz, A., Vincent, A., \& Berger, T. (2017). Daydreamer and night owl: Comparing positive and negative outcome cases in an online, clinicianguided, self-help intervention for social anxiety disorder. Pragmatic Case Studies in Psychotherapy, 13(3), 217252. doi: $10.14713 /$ pcsp.v13i3.2012

Spence, S. H., Donovan, C., \& BrechmanToussaint, M. (2000). The treatment of childhood social phobia: The effectiveness of a social skills trainingbased, cognitive-behavioural intervention, with and without parental involvement. Journal of Child Psychology and Psychiatry and Allied Disciplines, 41(6), 713-726. doi: 10.1017/S0021963099005934

Spence, Susan H., Donovan, C. L., March, S., Gamble, A., Anderson, R., Prosser, S., Kercher, A., \& Kenardy, J. (2008).
Online CBT in the treatment of child and adolescent anxiety disorders: Issues in the development of BRAVEONLINE and two case illustrations. Behavioural and Cognitive Psychotherapy, 36(4), 411-430. doi: 10.1017/S135246580800444X

Swasti, I. K., \& Martani, W. (2013). Menurunkan kecemasan sosial melalui pemaknaan kisah hidup. Jurnal Psikologi, 40(1), 39-58. doi: 10.22146/jpsi.7065

Thyer, B. A. (2002). Evaluation of social work practice in the new millenium: Myths and realities. In D. T. L. Shek, L. M. Chow, A. C. Fai, \& J. J. Lee (Eds.), Advances in Social Welfare in Hong Kong (pp. 3-18). Shatin, New Territories: New Asia College and The Chinese University Press.

Tillfors, M., Andersson, G., Ekselius, L., Furmark, T., Lewenhaupt, S., Karlsson, A., \& Carlbring, P. (2011). A Randomized Trial of Internet-Delivered Treatment for Social Anxiety Disorder in High School Students. Cognitive Behaviour Therapy, 40(2), 147-157. doi: $10.1080 / 16506073.2011 .555486$

Tillfors, M., Persson, S., Willén, M., \& Burk, W. J. (2012). Prospective links between social anxiety and adolescent peer relations. Journal of Adolescence, 35, 1255-1263.

doi:

10.1016/j.adolescence.2012.04.008

Vernberg, E. M., Abwender, D. A., Ewell, K. K., \& Beery, S. H. (1992). Social anxiety and peer relationship in early adolescence: A prospective analysis. Journal of Clinical Child Psychology, 21(2), 189-196. doi: 10.1207/s15374424jccp2102

WeAreSocial. (2019). Global Digital Report 2019. Retrieved from https://wearesocial.com/global-digitalreport-2019

Woods, A. P., Stults, C. B., Terry, R. L., \& Rego, S. A. (2017). Strengths and 
limitations of internet-based cognitive-behavioral treatments for anxiety disorders. Pragmatic Case Study in Psychotherapy, 13(3), 271-283. doi: $10.14713 /$ pcsp.v13i3.2015
Wright, J. H. (2006). Cognitive behavior therapy: Basic principles and recent advances. Focus, 4(2), 173-178. doi: $\underline{10.1176 / \text { foc. } 4.2 .173}$ 